\title{
A formação continuada do docente de língua portuguesa e o programa GESTAR II: da proposta oficial às necessidades do professor
}

\author{
Continuing education for teachers of Portuguese and \\ the GESTAR II program: from the official proposal to the teacher necessities
}

\author{
Rute ALMEIDA e SILVA* \\ Secretaria de Estado de Educação de Mato Grosso (Seduc/MT) \\ Maria Rosa PETRONI** \\ Universidade Federal de Mato Grosso (UFMT)
}

\begin{abstract}
RESUMO: Os Parâmetros Curriculares Nacionais (BRASIL, 1998) concebem a escrita como prática discursiva, vinculada a usos e funções sociais, admitindo um ensino-aprendizagem mais significativo e contextualizado, centrado no desenvolvimento de competências/capacidades linguístico-discursivas do aluno. Visam, ainda, à formação de produtores de textos competentes, capazes de elaborar escritas adequadas a cada situação sociocomunicativa. Cabe à escola a responsabilidade por tal ensino, garantindo-o ao aluno. As propostas oficiais de formação docente continuada, dentre as quais se destaca o GESTAR II - programa de formação continuada em serviço, destinado a professores de Língua Portuguesa do Ensino Fundamental - deve(ria)m fornecer ao docente essa fundamentação teórica. Considerando-se sua abrangência e aceitação, propomo-nos a analisar, em parte desse material, como dialogam as orientações teóricas e as propostas de produção escrita para professores e alunos. Nossa discussão sustenta-se na postura reflexiva e crítica da formação docente, assim como na concepção de língua(gem) e ensinoaprendizagem de escrita em perspectiva enunciativo-discursiva.
\end{abstract}

PALAVRAS-CHAVE: Formação docente. Prática discursiva. Competências linguísticodiscursivas.

\begin{abstract}
The National Curriculum Parameters conceive writing as a discursive practice linked to uses and social functions taking up a more meaningful and contextualized teaching and learning which is centered on the development of students' linguistic-discursive competences and capacities. Additionally, they aim at the formation of competent text producers capable of making writings right and proper to every social and communicative situation. It is up to the school responsibility to guarantee such teaching for students. The official proposals of in-service teacher education meant for teachers of Portuguese language of elementary education should provide the teacher with that theoretical foundation. Taking into consideration its scope and acceptance, we propose to analyze how the proposals for writing production of teachers and students and the theoretical orientations converse. Our discussion is based on the reflective and critical posture of teacher formation as well as in the conception of language and teaching and learning of writing under the enunciative and discursive perspective.
\end{abstract}

KEYWORDS: Teacher education. Discursive practice. Linguistic and discursive competences.

\footnotetext{
* Mestrado em Estudos de Linguagem; professora da Educação Básica da Secretaria de Estado de Educação de Mato Grosso (Seduc/MT). Cuiabá - MT - Brasil. Email: mocanegra@ hotmail.com.

${ }^{* *}$ Doutorado em Linguística; docente da Universidade Federal de Mato Grosso (UFMT), Departamento de Letras, Instituto de Linguagens, Programa de Mestrado em Estudos da Linguagem. Cuiabá - MT - Brasil. Email: rohpetroni@uol.com.br.
} 


\section{Introdução}

Desde o final da década de 1990, apublicação dos Parâmetros Curriculares Nacionais- PCN - (BRASIL, 1997) e Parâmetros Curriculares Nacionais de Língua Portuguesa - PCNLP -(BRASIL, 1998) tem provocadoalguns reflexos na educação brasileira, sobretudo, quanto ao novo direcionamento do ensino de Língua Portuguesa (doravante LP). Essa diretriz curricular, que traz em seu bojo concepções e perspectivas teórico-metodológicas classificadas como inovadoras, representa, atualmente, o ideal de ensino no país, poisadvoga a mudança efetiva no sistema educacional. Todavia, acreditamos que, para a efetivaimplantação dessas propostas aplicadas ao ensinoaprendizagem de língua materna, é preciso uma formação - inicial e continuada -eficiente e de qualidade, que contribua não só para a reflexão sobre as orientações desse material, mas também para a discussão de problemas e soluções, no tocante à prática pedagógica do professor.

Frente às atuais propostas curriculares, neste artigo propomo-nos a analisar como dialogam, em parte do material apresentado no Programa GESTAR II (BRASIL, 2008a; 2008b), as orientações teóricas e as propostas de produção escrita para professores e alunos, tendo em vista o aperfeiçoamento das práticas de leitura e escrita.

$\mathrm{Na}$ seção seguinte, são abordados aspectos dos PCNLP (BRASIL, 1998), relacionados ao professor e sua prática.

\section{0 professor de língua portuguesa e os parâmetros curriculares nacionais}

Os PCN (BRASIL, 1998) constituem-se em uma proposta do MEC, cuja finalidade principal é melhorar a qualidade da educação brasileira, garantindo às crianças e aos jovens o acesso aos conhecimentos necessários para sua integração na sociedade moderna como cidadãos ativos e responsáveis. Os pressupostos de tais diretrizes centram-se no desenvolvimento de capacidades linguístico-discursivas do aluno, no ensino contextualizado e significativo e, especialmente, na formação de um indivíduo crítico, consciente e participativo, capaz de intervir no meio social do qual participa.

Esses documentos, destinados a um público diversificado de professores, de diferentes regiões do país, apresentam-se não só como um referencial, mas também como um conjunto de reflexões que objetivam alimentar a prática pedagógica do educador, trazendoalternativas teórico-metodológicas adequadas ao ensino a partir do uso da linguagem contextualizada, privilegiando, desse modo, o trabalho com os gêneros do discurso. Isso equivale a dizer que, na sala de aula, o ensino-aprendizagem da leitura e da escrita, especificamente, deve partir do uso genuíno da língua(gem), permitindo aos alunos desenvolverem novas capacidades. A opção por esse ensino mais significativo, ocorrida no final do século XX, é resultado de um forte apelo, primeiro da Academia e depois de algumas ações governamentais, em prol da leitura e, necessariamente, da escrita de textos que fazem parte do universo extraescolar dos alunos, a fim de torná-los leitores e escritores proficientes e críticos, conforme lembra Paes de Barros (2008).

Segundo a autora, é justamente nesse contexto que gêneros pertencentes a diferentes esferas sociais (publicitária, artística, religiosa, entre outras) ganham espaço no meio escolar, como instrumento de ensino-aprendizagem dessas práticas. Por isso, é impossível não admitir que tal parâmetro, apesar das críticas que recebe(u), representa um avanço nas políticas educacionais brasileiras, principalmente, em relação ao ensino-aprendizagem de escrita sob um enfoque enunciativo-discursivo. Seu valor social deve ser reconhecido e 
enfatizado, como bem destacam vários autores, posto que os Parâmetros têm sua atuação "nas políticas linguísticas contra o iletrismo e em favor da cidadania crítica e consciente" (ROJO, 2001, p. 27). Além disso, trazem contribuições valiosas para o campo do conhecimento didático-pedagógico da atuação docente em sala de aula, bem como para o processo interlocutivo entre professor e aluno, destacando-se, sem dúvida, como subsídio e orientação que auxiliam o educador em seu cotidiano escolar.

Em virtude disso, compreendemos que sua efetivação, assim como a adoção da proposta veiculada nesse documento oficial,constitui-se em um desafio para o docente, sobretudo para aquele formado há mais tempo, que não teve contato com os conceitos trazidos por tal diretriz. Assim, para um ensino de língua materna mais concreto, que forme sujeitos críticos e conscientes do seu papel social, é preciso oportunizar ao educador não leituras simplificadas (às vezes, rasas), mas aprofundamentos teóricos, metodológicos, conhecimento amplo a respeito de teorias várias que embasam as orientações oficiais, com a devida atenção que um estudo como esse merece. Nas palavras de Pompílio et al. (2001), um aprofundamento das teorias que compõem os PCN (BRASIL, 1998) demanda práticas mediadoras que permitam uma discussão, de fato, sobre o que neles se propõe. Isso compreende, sem dúvida, um trabalho de formação docente continuada, além da elaboração de textos de apoio, nos quais se esclareçam algumas de suas ideias, e da confecção de materiais didáticos que respondam às questões propostas por essa diretriz curricular. Só assim haverá uma efetiva transformação do espaço escolar.

Nessa mesma direção, partilhamos a opinião de Barbosa (2001), ao reconhecer o valor de tal documento para a educação e destacar: "para que seus efeitos possam ser potencializados a médio e a longo prazos, fazem-se necessárias outras modalidades de intervenção" (BARBOSA, 2001, p.149). Por essa razão, reafirmamos que é preciso uma real formação continuada de professores e demais educadores, com investimentos maciços na formação e na qualificaçãodesses profissionais.

Em relação à formação docente, Brito (2006) esclarece que, antigamente, formar professores consistia em dotá-los de competências e habilidades instrumentais, apoiando-se em modelos tecnocratas, que os preparavam para o "saber-fazer". Entretanto, os tempos mudaram, por isso, nos dias atuais, há emergência de novas reflexões sobre a formação e a prática docente. Para a autora, essas reflexões dizem respeito ao delineamento de uma nova racionalidade formativa, cujo objetivo é formar um professor que, além de dominar os saberes específicos da sua profissão, constitua-se como um indivíduo capaz de responder às diversas situações presentesna práxis docente. Dessa forma, impera a necessidade de um profissional muito bem qualificado, exercendo a docência de modo efetivo nessa sociedade tão complexa, o que demanda, inevitavelmente, uma educação docente continuada eficiente, diferente daquela transmissiva, ligada ao praticismo pedagógico e à racionalidade técnica. Necessita-se, portanto, de uma formação que permite ao professor assumir postura autônoma, crítica e reflexiva, e o traga para o centro do processo, fazendo-o refletir sobre sua própria prática e transformando-a. Impõe-se, desse modo, a necessidade de uma educação que valorize as ações pedagógicas do professor, preparando-o efetivamente para enfrentar as mudanças educacionais da sua época.

Ressaltamos essa necessidade, apesar de reconhecermos que programas de capacitação profissional existem; no entanto, tem-se observado que muitos dos cursos oferecidos por esses programas nem sempre consideram o principal agente do processo de ensino: o professor. Além disso, não tratam, com o devido aprofundamento, as abordagens teórico-metodológicas, oferecendo, muitas vezes, materiais didáticos incoerentes com a proposta atual de ensino-aprendizagem de LP, contribuindo pouco para a qualificação desse profissional. Um exemplo dessa incoerência pôde ser observado por Magalhães (2004, p. 61), na sua lida com a formação contínua de educadores, em relação ao modo 
como as concepções de linguagem, de mundo, de ensino-aprendizagemsão enfocadas nesse contexto. Segundo a autora, o tratamento desses assuntos nem sempre possibilita ao cursista "a desconstrução de representações tradicionais que têm uma sólida base em uma pedagogia que entende ensino-aprendizagem como transmissão e devolução de conhecimento e está apoiada em um conceito estruturalista de linguagem" (MAGALHÃES, 2004, p.61). Essa autora relembra ainda que muitos desses cursos oferecem ao participante um "pacote" de novidades, com teorias inovadoras e receitas prontas que não alteram a práxis docente. Os responsáveis por tais cursos parecem mesmo acreditar que somente o conteúdo seja suficiente para preparar esse profissional.

Em face dessas constatações, compreendemos que uma formação inadequada pode levar, de fato, o professor a reproduzir na sala de aula conteúdos teóricos insuficientes e/ou descontextualizados. Por essa razão, entendemos que a formação continuada é/deveria ser o espaço ideal não só para refletir sobre as práticas pedagógicas atuais e/ou antigas, a vida pessoal e profissional do professor, como também para desconstruir saberes cristalizados e, principalmente, construir outros saberes condizentes com as reais necessidades e/ou expectativas dos alunos.

Essa ideia parece aproximar-se daquela assumida, desde os anos 1990, sobre a formação de um professor reflexivo, conceito de profissional revitalizado por Donald Schön (1992), que defende uma formação docente fora dos moldes normativos, ou seja, daqueles que dão ênfase à transmissão do conhecimento e em que se apresentam primeiro os princípios científicos e depois sua aplicação. Esse autor propõe uma educação reflexiva, desde a formação inicial (até a continuada), embasada no tripé conhecimento na ação (saber-fazer), reflexão na ação (pensar sobre o fazer), reflexão sobre a ação e sobre a reflexão na ação (analisar criticamente o saber fazer). Sem dúvida, esse modelo possibilita um olhar diferenciado para a educação atual, favorecendo uma formação docente mais concreta, adequada às novas exigências do mundo globalizado. Nessa perspectiva, o saber sobre o ensino não se antecipa ao fazerpedagógico, como estabelecia o modelo tradicional. Ao contrário, parte-se da prática, do conhecimento na ação, refletindo sobre ela e questionando-a, embasadopelo saber teórico; depois, compreendem-se os problemas e conflitos vivenciados na sala de aula, analisando-os criticamente, criando meios para solucioná-los.

Tal postura reflexiva permite, de fato, ao aluno/professor a discussão, a comparação, a investigação, bem como a participação no seu processo de construção de conhecimento, visto que, nessa concepção, cada situação problemática, na escola, por exemplo, é entendida na sua peculiaridade, devendo ser tratada dentro do seu contexto imediato, sem, necessariamente, o rigor das aplicações técnicas. Porto (2000) entende que as práticas crítico-reflexiva, criativo-inovadora, autônomo-transformadorapassam a se impor como condição construtiva da vida pessoal e profissional do educador, rompendo, evidentemente, com o conhecimento produzido fora da profissão docente, descontextualizado. Desse modo, a formação continuada, que está associada ao processo qualitativo de práticas formativas e pedagógicas do professor, passa a adotar como referências as dimensões coletivas das práticas, contribuindo para a autonomia e para a consolidação da profissão docente. Nessa perspectiva, o professor é capaz de construir o conhecimento pedagógico a partir do cotidiano escolar, desenvolvendo, assim, uma prática transformadora e um processo contínuo de reflexão na e sobre a ação.

Advogando em nome da eficácia dos modelos de educação continuada que investem na formação do professor enquanto profissional reflexivo, Kleiman (2001, p. 248) propõe uma (auto)formação via letramento, por meio de um processo reflexivo. A formação docente constituída de práticas letradas, voltadas não só para sua vida profissional como também individual, compreende "a autonomia do professor através da 
transformação e do enriquecimento de suas práticas de leitura e escrita". Nesse molde, tal processo ocorre primeiramente na instância pessoal, para depois e/ou simultaneamente mostrar sinais na vida profissional, além de considerar as necessidades reais de conhecimento do educador e as dificuldades enfrentadas por ele na sala de aula.

$\mathrm{O}$ conceito de letramento, muito utilizado no ensino vigente, diz respeito à capacidade de os indivíduos usarem efetivamente a leitura e a escrita para resolver suas questões, nos diversos contextos sociais. Atualmente, não basta saber desenhar letras ou decifrar códigos; é preciso bem mais do que isso: entender os significados e usos das palavras nos diferentes espaços comunicativos. Por essa razão, afirmamos que, nas discussões educacionais, em qualquer espaço social, especialmente no escolar, não se pode jamais perder de vista o professor, suas particularidades e suas experiências. Afinal, ele é a "peça chave" nesse imenso quebra-cabeça; por isso, não basta alterar métodos e teorias curriculares sem considerar, de fato, o principal agente do processo de ensinoaprendizagem, o professor. Entretanto, temos percebido que, das várias discussões sobre educação escolar, especialmente daquelas veiculadas na mídia, o professor de LP parece não participar, efetivamente, ficando às vezes no meio de "um fogo cruzado". Na verdade, ele acaba sofrendo com tantas mudanças educacionais, com tantas críticas à sua prática docente, com os inúmeros questionamentos sobre seu processo formativo, sua profissão, seu letramento e sua vida. Aliás, ao longo da história, o educador vem enfrentando diversas críticas sobre sua práxis pedagógica, além de sofrer com o desprestígio da sua profissão, a falta de estrutura no espaço de trabalho, baixos salários, sobrecarga de serviço, entre outros fatores. Em meio a tudo isso, muitas vezes, ele, como cidadão, é esquecido e ignorado. A esse respeito, Nóvoa (2009, p. 22) nos faz relembrar da ausência do professor nessas discussões, nos dias atuais: "fala-se muito das escolas e dos professores. Falam os jornalistas, os colunistas, os universitários, os especialistas. Não falam os professores".

Essa constatação mostra a ocorrência, sistemática, de uma espécie de silenciamento da profissão, que, de certo modo, perdeu sua visibilidade nas relações sociais. Por isso, o pesquisador também defende a necessidade de se construírem, urgentemente, políticas públicas que reforcem o educador, seus saberes, seu campo de atuação e que valorizem, efetivamente, a sua cultura. Vale ressaltar que o lugar de formação constitui-se em um espaço fundamental capaz de reforçar essa presença pública do professor na sociedade.

Entendemos que as inúmeras transformações na educação devem ser compreendidas dentro de um contexto sócio-histórico, porque, como é sabido, a democratização do ensino trouxe um aumento significativo do número de alunos para a escola, implicando, obviamente, o aumento de professores. Entretanto, para atender à demanda, a formação desses profissionais ocorreu, muitas vezes, de modo indiscriminado e com a oferta de cursos rápidos, nem sempre de qualidade, contribuindo, assim, para a fragilidade do sistema, segundo Matencio (2000, apud STRIQUER, 2009).

$\mathrm{Na}$ defesa de que essas mudanças educacionais sejam acompanhadas de reflexões concretas, tanto sobre a formação quanto sobre o perfil socioeconômico-cultural docente, Silva, Assis e Matencio (2001) relembram o fato de que ultimamente tem chegado às diversas universidades do país, por exemplo, um alunado de Letras com defasagem em leitura e escrita. Isso ocorre, certamente, porque a maioria desses alunos não teve acesso a tais práticas na sua infância ou ao longo de sua vida escolar e extraescolar. O que se encontra, geralmente, nos espaços acadêmicos, são alunos com pouca familiaridade com as novas tecnologias e que, por trabalharem durante o dia e estudarem à noite, não têm condições de se dedicar ao estudo fora do seu horário de aula. Além do mais, muito desses graduandos provêm de famílias de baixa escolaridade, de grupos socialmente desfavorecidos, para as quais sua entrada numa universidade, especialmente na pública, representa uma grande conquista, resultante do seu esforço e sacrifício em busca de 
ascensão social. Portanto, todas essas questões não devem ser ignoradas, principalmente, nos espaços de formação continuada. Tendo em vista esses profissionais como atores humanos, prenhes de histórias, de ações e práticas (SILVA, 2006), é preciso considerar as possibilidades das quais usufruíram ao longo da sua vida,

as restrições pelas quais passaram, inventariar as situações vividas e as formas como as enfrentam, bem como os comportamentos advindos de sua ação no mundo social [...] é necessário debruçar-se sobre os fatores sociais, considerando as diversas esferas da atividade humana determinadas por sua inserção cultural, responsáveis pelo desenvolvimento psíquico dos sujeitos (VÓVIO; SOUZA, 2005, p. 46).

Atualmente, educar, na heterogeneidade das situações, sujeitos capazes de atuarem competentemente nas diferentes esferas de atividade humana constitui grande desafio para qualquer profissional da educação (SOCORRO, 2009). Hoje, a sala de aula é concebida como um espaço complexo, onde o professor encontra dificuldades de toda ordem, onde várias coisas acontecem ao mesmo tempo, escapando, às vezes ao seu controle (SILVA, 2006). É exatamente nesse contexto que o docente precisa mobilizar os mais variados saberes para solucionar problemas e para enfrentar situações que surgem no interior dessa instituição. Segundo Brito (2006), para resolver questões escolares, o professor precisa mobilizar não só o conhecimento teórico, como também o experiencial. Isso equivale a dizer que sua ação não pode se limitar à mera aplicação e transmissão de conhecimentos técnicos; ao contrário, ele precisa ser capaz de transformar esses saberes diante da situação complexa que é a sala de aula. Essa afirmação remeteà inter-relação entre teoria educacional e prática docente, ou à desarticulação que muitas vezes existe entre ambas.

Sabemos que a grande crítica existente hoje é que muitos cursos de formação docente, tanto inicial como continuada, nem sempre conseguem relacionar essas duas "modalidades". Ao contrário, reduzem-nas a uma dicotomia estanque, expondo o futuro professor à disciplina teórica, mas não o levando a realizar a aplicação dos saberes aprendidos para a situação prática na sala de aula. Muitos cursos ainda desenvolvem um currículo composto de conteúdos teórico-metodológicos em que não há confrontos, reflexões e nem análises de seus elementos constitutivos; disso advém a grande dificuldade encontrada pelos alunos/professores em colocá-los em prática. Entretanto, a situação atual requer desses profissionais que reflitam diariamente sobre e durante suas práticas pedagógicas. Nesse aspecto, a formação por meio dos moldes reflexivos representa um caminho promissor para mudanças efetivas na educação. $\mathrm{O}$ apoderamento efetivo visado nessa perspectiva possibilita ao educador compreender, entre vários fatores, os problemas constantes da falta de articulação entre teorias e práticas pedagógicas, visto que esse tipo de profissional se caracteriza, justamente, como um indivíduo criativo, capaz de significar e ressignificar o ensino, analisando e criticando a sua própria prática, a fim de agir sobre ela, modificando-a. Na perspectiva crítico-reflexivo, o professor deixa de ser considerado um simples "aplicador de teorias" e assume o papel de quem também produz e constrói conhecimentos, a partir dos seus saberes e experiências.

Em relação a esse pensamento contemporâneo, Oliveira (2006, p. 102) alerta para o risco de serem criados outros "mitos", baseados na ilusão de que apenas a observação e a reflexão sobre a sala de aula ajudariam a entendera prática docente. À preocupação da autora acrescentamos as palavras de Nóvoa (2009, p. 33): "não se trata de adoptar uma qualquer deriva praticista e, muito menos, de acolher as tendências anti-intelectuais na formação de professores". Ao contrário, "trata-se de abandonar a ideia de que a profissão docente se define, primordialmente, pela capacidade de transmitir um determinado saber". 
Mesmo o foco das discussões tendo se deslocado para a prática dos professores, compreendemos que, de modo algum, deve-se descartar o debate sobre o papel da teoria, dos conhecimentos científicos, em sala de aula, nos cursos de formação inicial ou continuada: a reflexão sobre a prática, sobre a ação, não dispensa a reflexão sobre a teoria, as quais devem ser tratadas como uma unidade, indissociavelmente.

Com a finalidade de tentar promover essa articulação em nível de formação continuada, o Ministério da Educação (MEC) lançou o Programa Gestão da Aprendizagem Escolar, atualmente na segunda versão (doravante, GESTAR II), cujo foco é a melhoria do aprendizado dos alunos e o desenvolvimento de competências dos educadores. Um dos objetivos desse programa é habilitar o professor para a prática efetiva do ensinoaprendizagem da escrita, possibilitando-lhe o desenvolvimento das capacidades de linguagem implicadas no processo de produção de textos.Dominar tais capacidades é condição para o sucesso, tanto do professor quanto do aluno,nesse processo de ensinoaprendizagem.

Defendendo o ensino sistemático da comunicação oral e escrita, Schneuwly e Dolz (2004, p. 52) afirmam que

\begin{abstract}
a noção de capacidades de linguagem [...] evoca as aptidões requeridas do aprendiz para a produção de um gênero numa situação determinada: adaptar-se às características do contexto e do referente (capacidades de ação); mobilizar modelos discursivos (capacidades discursivas); dominar as operações psicolingüísticas e as unidades lingüísticas (capacidades lingüístico-discursivas) (SCHNEUWLY; DOLZ, 2004, p. 52).
\end{abstract}

Ainda segundo os autores, a análise de tais capacidadespermite avaliar o desenvolvimento das práticas de leitura e escrita dos aprendizes no processo de ensinoaprendizagem, destacando a importância de "produzir, compreender, interpretar elou memorizar um conjunto organizadode enunciados orais ou escritos" (SCHNEUWLY; DOLZ, 1999, p. 6) como ações integradas nesse processo.

Em nossa pré-analise dos materiais (TP6 e Guia Geral), fazemos uso do conceito de capacidades de linguagem, a partir das quais observamos que os autores se propõem, no tratamento didático para a produção escrita, a levar em conta a situação sóciocomunicativa, a saber, elementos da situação de produção, circulação e recepção. Dessa forma, na unidade 22, do TP6, analisamos as orientações dadas ao professor e ao aluno para a produção textual, buscando identificar as capacidades de linguagem presentes nessas propostas de ensino-aprendizagem, pois acreditamos que, antes de desenvolver as capacidades do aluno, o professor precisa, naturalmente, ter desenvolvido as suas. Para tanto, aplicamos as categorias de análise das capacidades de linguagem proposta por Schneuwly e Dolz (2004), a partir do quadro ${ }^{1}$ síntese elaborado por Barros-Mendes (2005) e adaptado por nós, a propósito do nosso objetivo, conforme segue:

\footnotetext{
${ }^{1}$ Barros-Mendes (2005, p. 121) elaborou esse quadro baseada nas capacidades de linguagem de Dolz e Schneuwly (1998), para verificar quais das respectivas capacidades (orais) estavam presentes na didatização de alguns gêneros orais de uso público em livros didáticos de LP. Diante disso, é válido elucidar que tomamos esse quadro como base para nossa análise sob um outro olhar, uma vez que nosso objeto de estudo propostas de escrita, dentro de um material didático destinado à formação continuada de professoresdistingue-se daquele discutido pela pesquisadora mencionada. Para analisar esse material, vamos assumir tal quadro, pois percebemos que é possível tomá-lo para observar o tratamento didático dos gêneros no Caderno de formação, quanto à produção textual.
} 
Quadro 1 - Síntese das capacidades de linguagem

1. CAPACIDADES DE AÇÃO (definição clara sobre o objeto, ou seja, sobre o gênero)

a) Gênero: O Livro de Português (LDP) informa o gênero a ser trabalhado?

b) Participantes: O LDP orienta, em relação a cada gênero, sobre os possíveis locutores/interlocutores?

c) Contexto de produção textual: o LDP permite entrever o contexto onde o gênero será construído ocorrerá?

d) Finalidade: $\mathrm{O}$ aluno sabe por que desenvolve a atividade num determinado gênero? É orientado no sentido de estar consciente de um trabalho que vise ao domínio de algumas capacidades de linguagem como aprender a explicar, refutar, se posicionar etc.?

e) Conteúdo: Informa o conteúdo a ser trabalhado?

2. CAPACIDADES DISCURSIVAS (o que pode ser dito através desse objeto e a organização desse dizer no objeto, auxiliando tanto para o tema quanto à forma de composição do gênero)

a) Elaboração dos conteúdos do gênero: O LDP fornece informações para a construção/elaboração dos conteúdos do gênero?

b) Plano do texto/organização textual: a organização sequencial é indicada de acordo com o gênero?

\section{CAPACIDADES LINGÜÍSTICO-DISCURSIVAS (como pode ser dito, auxiliando no estilo do gênero)}

a) Operações de textualização: orientação sobre a conexão/coesão de acordo com gênero. Por exemplo, o debate requereria o uso de conectivos de justificação/explicação (pois, porque) e contraposição (no entanto, mas, porém).

b) Escolha lexical: O LDP orienta sobre o vocabulário apropriado ao gênero e conforme a situação de comunicação?

c) Tomada de posição enunciativa ou ponto de vista enunciativo: o LDP trata das relações entre as diferentes vozes que podem aparecer dentro de um texto? Orienta as modalizações, apreciações valorativas etc.?

(Fonte: BARROS-MENDES, 2005, p. 121)

Além das capacidades de linguagem, ao assumirmos a perspectiva discursivoenunciativa do Círculo de Mikhail Bakhtin (2004[1929], 2003[1952-1953]), mobilizamos para nossas análises alguns conceitos forjados no interior da perspectiva bakhtiniana, a saber: gêneros do discurso, diálogo, interação e compreensão ativa e responsiva.

A perspectiva dialógica da linguagem e o conceito de gênero discursivo, tal como postulados pelo Círculo de Bakhtin acima referenciado, constituem os pilares da nossa pesquisa, pois norteiam não só a coleta de dados, como também sua análise. Sob tal perspectiva, o ensino da produção de textos procede (noutros moldes, diferentes daqueles tradicionais), sobretudo, pela adoção de um gênero do discurso adequado à situação comunicativa em foco. Logo, numa atividade de escrita, a definição da esfera de atividade, bem como do interlocutor, do propósito comunicativo, das condições de produção, circulação e recepção, entre outros, precisam ser levados em conta, pois se constituem em aspectos fundamentais capazes de permitir, de fato, ao aprendiz um entendimento satisfatório das situações sociais concretas em que a linguagem se realiza.

Nesse sentido, a análise de propostas de produção textual, através da concepção enunciativo-discursiva, permite perceber a presença desses elementos que não podem, jamais, ser deixados em segundo plano, no processo de escrita. Aliás, um trabalho que se 
propõe a seguir os atuais paradigmas teóricos de ensino de LP deve trazer claras essas características, considerando o processo de escrita como uma interlocução real, já que o "discurso só pode existir de fato na forma de enunciações concretas de determinados falantes, sujeitos do discurso" (BAKHTIN, 2003[1952-1953], p. 274).

Para nós, o conceito de gêneros do discurso, por envolver as diferentes formas de dizer nas variadas esferas sociais e situações discursivas, mantém uma relação direta com o conceito de letramento. Sabe-se que o nível de letramento de um sujeito é determinado, essencialmente, pela variedade de gêneros que ele reconhece e domina na sociedade. $\mathrm{Na}$ sala de aula, tais gêneros possibilitam a (re)criação e a (re)contextualização das interações sociais.

Ao inscrevermos nosso estudo nesses referenciais teóricos, é impossível não levarmos em conta a teoria sócio-histórica de Vygotsky (2007 [1984], 1996[1987]), cujos fundamentos também foram utilizados na composição dos documentos oficiais vigentes, bem como no redirecionamento do ensino de LP. Nesse aspecto, concordamos com Freitas (2006), para quem o princípio vygotskyano, além de possibilitar o conhecimento da evolução do desenvolvimento humano e do processo de apropriação do saber pelo indivíduo, apontou para um caminho mais eficaz e comprometido com e para a prática pedagógica docente. É fato que a atual tendência educacional tem um caráter mais social, mais dialético e considera o homem não só como um indivíduo influenciado pelo meio, mas também com capacidade de se voltar sobre ele para transformá-lo (FREITAS, 2006, p.15-16). Por isso, as concepções vygotskyanas acerca do desenvolvimento humano e da interação social também servem de categoria de análise dos dados coletados.

Na sequência, apresentamos breve descrição do material de formação continuada selecionado para a análise.

\section{GESTAR II: caderno de teoria e prática - TP 6 - Unidade 22}

O GESTAR II é um programa de formação continuada, destinado a docentes que atuam no Ensino Fundamental em atividade nas escolas públicas brasileiras. Tal Programa se apresenta como um conjunto de ações articuladas a serem desenvolvidas junto aos professores de Matemática e de Língua Portuguesa. Seu principal objetivo é a melhoria do processo de ensino-aprendizagem, visto que mantém seu foco na atualização dos conhecimentos dos educadores; além do mais, tem a intenção de aprimora a competência profissional desses profissionais, para a melhor formação de seus alunos, a fim de permitir a todos a real compreensão da realidade sociocultural que os cerca e uma possível ou efetiva intervenção sobre ela. Compõe-se de um conjunto de cadernos: os de teoria, denominados Teoria e Prática (TP), os de Atividades de Apoio à Aprendizagem, denominados AAA, na versão do professor e na versão aluno, além do Guia Geral. Esses materiais, publicados no ano de 2008, estão em evidência em grande parte do país, sendo amplamente utilizados na capacitação dos profissionais da educação. Além disso, suas orientações teóricas buscam seguir os pressupostos dos PCNLP (BRASIL, 1998), o que confere, de fato, relevância aos dados aqui discutidos.

Com o objetivo de obtermos informações que melhor descrevessem as propostas de produção de textos no material de apoio à formação docente continuada, buscamos, como fonte documental para a investigação, o Caderno TP6 do GESTAR II e, consequentemente, o Guia Geral, caderno em que se encontram informações relativas aos pressupostos teóricometodológicos do Programa GESTAR II. Comentamos a Unidade 22 do TP6, relativa aos pressupostos teórico-metodológicos que embasam a prática pedagógica do professor de Língua Portuguesa para o ensino de escrita, para, em seguida, discutirmos a análise das 
propostas de produção textual direcionadas ao aluno, buscando também reconhecer as capacidades mobilizadas para o exercício da escrita do aluno.

Assim, tomamos o TP6, uma vez que trata, sobretudo, do processo de produção de textos. Esse caderno, intitulado Leitura e processos de escrita II, dá continuidade à elaboração dos conceitos e práticas para o trabalho pedagógico do professor e ao trabalho com gêneros, com o estudo da argumentação. Nele é retomada a produção textual, com a apresentação das fases de planejamento, escrita, revisão e edição. Além de percorrer essas etapas de produção, é proposta uma ligeira reflexão sobre as estratégias utilizadas nessas fases. Esse material, embora seja um caderno direcionado ao professor cursista, contém sugestões de atividades práticas a serem aplicadas em sala de aula com o aluno.

No TP6, nosso olhar recaiu sobre as orientações de escrita direcionadas não só para o professor, como também para o aluno, a fim de compará-las em termos da mobilização das capacidades de linguagem exigidas no processo de produção textual. Sabemos que o professor precisa, primeiramente, desenvolver suas capacidades de linguagem para poder ensinar seu aluno. Logo, o curso de formação continuada se constitui em um espaço ideal para isso.

Com nossa análise, verificamos também se, e em que medida, as propostas contidas nesse documento são orientadas pela e para a tendência atual de ensino de escrita, possibilitando aos professores o real desenvolvimento das capacidades de linguagem requeridas no processo de produção de textos diversos. Em seguida, comparamos as orientações destinadas ao docente no processo de escrita com o encaminhamento didático das atividades de produção dirigido ao aluno, com o intuito de identificar se as mesmas capacidades mobilizadas no ensino-aprendizagem do professor são contempladas nas propostas de produção textual do aluno.

$\mathrm{Na}$ sequência, apresentamosa análise da Unidade 22 do TP6, referente aos pressupostos teórico-metodológicos, que embasam a prática pedagógica do professor de Língua Portuguesa para o ensino de escrita, para, em seguida, discutirmos a análise das propostas de produção textual direcionadas ao aluno, buscando também reconhecer as capacidades mobilizadas para o exercício da escrita do aluno.

\subsection{Apresentação do TP6}

O Caderno de Teoria e Prática traz quatro unidades, cada qual contendo três Seções, e se divide em três partes: Parte I: Unidades; Parte II: Lição de Casa ou Socializando e Parte III: Oficinas ou Sessão Coletiva.

Na parte I, encontram-se o Título da Unidade e o nome do autor; o Iniciando Nossa Conversa, em que se introduz a unidade ao professor; o Definindo Nosso Ponto de Chegada, em que se descrevem os objetivos de aprendizagem; as Seções, em número de três, cada qual apresentando título, objetivos de aprendizagem e o desenvolvimento do conteúdo.

No término de cada Unidade, existem: Bibliografia, na qual é apresentada toda a base teórica da Unidade, eLeituras Sugeridas, em que são feitas propostas de leituras (de três a cinco por Unidade). Cada uma dessas sugestões possui, além de resenhas, referências bibliográficas. Dentro da Unidade, há ainda os itens: Ampliando nossas Referências, no qual se apresenta um Texto de Referência, relacionado a conteúdos vistos na Unidade, a fim de enriquecer a reflexão do professor cursista sobre sua prática; Correção das Atividades, em que o professor tem a oportunidade de conferir as respostas das questões distribuídas ao longo da Unidade. 


\subsection{TP6 - Produção textual: planejamento e escrita}

Na Unidade 22 do TP6, intitulada Produção textual: planejamento e escrita, nosso olhar lança-se para aSeção III, intitulada A escrita,cujo objetivo principal é o desenvolvimento de "atividades de planejamento e escrita, considerando a construção e a revisão textual” (BRASIL, 2008a, p. 102).

Consideremos a atividade de número cinco, dedicada às questões sobre a prática pedagógica do professor e seu processo de escrita. Tais questões são acompanhadas de textos que abordam o processo de planejamento e revisão e a importância de se refletir sobre o processo de escrita do professor e do aluno:

a) Faça um exercício para lembrar o que ocorreu durante a escrita do texto da atividade 4. Houve planejamento durante a escrita? Houve revisão, durante a escrita? Descreva lembranças sobre o que ocorreu.

b) Observe seus alunos durante a escrita de um texto. O que seus movimentos, olhares, silêncios, sussurros e perguntas the dizem sobre seus processos de escrita? (BRASIL, 2008a, p. 102).

Vejamos o excerto apresentado no material de formação docente:

A própria produção do texto em si requer uma junção de alguns elementos de planejamento e de revisão. Quanto ao planejamento, pudemos ver que temos dois processos básicos. Um desencadeado por escritores sem experiência em que o autor produz buscas superficiais sobre os temas, utilizando apenas o conhecimento prévio sobre o assunto até que pense que respondeu ao comando de seu leitor, o professor. Percebemos que devemos intervir e transformar esse processo (baseado apenas em uma busca na memória de caráter associativo) em um processo em que o escritor comece a relacionar sua escrita a um processo comunicativo.

Vimos nas seções anteriores que podemos trabalhar o planejamento de várias formas e utilizando várias estratégias; porém, durante a escrita, há um tipo de planejamento que é diferente. O planejamento durante a escrita requer que tenhamos nossos objetivos em mente e, comparando-o com o que estamos gerando na escrita, vamos modificando a escrita e o próprio planejamento visando à formulação de significados e da lógica textual. Isto se aprende ao longo dos anos com muita prática reflexiva.

Quanto ao processo de revisão, ocorre de forma superficial, localizada no momento em que voltamos para corrigir algo, deixamos algum trecho ou um significado/idéia para a qual não conseguimos encontrar um termo adequado no momento. A revisão pode ocorrer quando notamos algum problema de coesão também. Mas esta atividade de revisão durante a escrita não ocorre a todo momento, porque atrapalharia a escrita que vai em direção ao seu objetivo final. O importante neste período da aprendizagem da escrita é chamar a atenção dos alunos para as possibilidades de prática criando oportunidades iniciais para o estabelecimento de um diálogo dos autores com seus próprios textos e com textos de outros escritores iniciantes e experientes.

(BRASIL, 2008a, p. 102-103).

Em relação ao planejamento, o TP reitera o que foi dito em seções anteriores: podemos trabalhá-lo de várias maneiras, utilizando diversas estratégias; durante a escrita esse processo é diferente, pois requer objetivos claros etc. A respeito da correção superficial, parece haver equívoco ou, no mínimo, falta de clareza quanto à afirmação feita. No processo de produção escrita, não há nenhuma atividade que possa ocorrer de modo superficial, especialmente se se tratar de reflexão sobre esse processo. Tampouco deve ser 
estimulada tal prática. Essa afirmação, feita em um material oficial de formação docente, choca-se com a proposta de atualização de conceitos e metodologias.

Após as orientações teóricas, o TP6 fornece a atividade de número seis, com o seguinte encaminhamento:

a) Considere a sua experiência pessoal com a escrita de diferentes textos. Como você escreve e que estratégias usa para iniciar, desenvolver e finalizar os seguintes textos:

al) Uma carta:

a2) Um relatório para a escola:

a3) Uma prova de português:

(BRASIL, 2008, p. 103).

Podemos observar que essa atividade não traz, de modo claro, o objetivo do exercício e, muito menos, as capacidades que se pretendem mobilizar. Além disso, as características dos gêneros discursivos indicados para produção não são destacadas. Também não há qualquer direcionamento para a reflexão sobre a prática dessa produção. Desse modo, acaba gerando certa expectativa, porque podemos imaginar que, depois de realizar tal tarefa, certamente, o professor receberá alguma orientação mais concreta sobre o modo de esquematizar e de escrever tais gêneros. Mas não é o que ocorre. Ou, talvez, em algum outro TP o professor-cursista já tenha sido orientado para tais construções; nesse caso, o materialdeveria, no mínimo, lembrá-lo disso, trazendo alguma referência. Sabemos que tal escrita se configura com um desafio para o produtor, porque ele deve dialogar com outros discursos, replicando-os. Isso requer, obviamente, a mobilização das capacidades de linguagem envolvidas no processo. Embasados na visão bakhtiniana, entendemos que toda produção textual, como um ato interlocutivo, implica sempre uma compreensão responsiva ativa e criadora para a construção dos sentidos de um texto.

Os dados dessa questão nos levam a pensar que, talvez, a proposta seja apenas uma forma de fazer referência às atuais orientações para o ensino, sem maiores consequências.

Em seguida, o TP6 fornece mais um pequeno texto tratando da necessidade de o educador refletir sobre seu processo de escrita, para mais tarde discutir também o processo do aprendiz. Destaca a possibilidade de se ensinar ao aluno algumas estratégias durante a escrita, como, por exemplo, a de deixar espaços em branco para depois ir ao dicionário consultar o termo mais adequando.

É importante refletirmos sobre os nossos processos para podermos nos comunicar com nossos alunos e discutirmos seus processos de escrita, também. Escrever não é se ater sempre ao planejado, mas ir além para que os alunos aprendam que podem ter opções diferentes durante a escrita. Como vimos, podemos ensinar estratégias, também durante a escrita: pode-se deixar espaços em branco para que possamos depois ir ao dicionário, por exemplo, para consultar o termo mais adequado ou mesmo nos lembrarmos quando formos reler o texto do termo que queríamos utilizar e nos fugira na hora da escrita.

(BRASIL, 2008a, p. 104)

Após essas orientações, o Caderno TP6 apresenta as seguintes questões:

a) Como foi (e é) o desenvolvimento de sua competência escrita? Como você faz para escrever melhor? 
b) Como você acha que os seus alunos desenvolvem e desenvolverão a escrita? O que pode fazer para melhorar esse desempenho? (BRASIL, 2008a, p. 104).

Embaixo de tal encaminhamento, o material traz mais orientação para o professorcursista, lembrando-o de que, a cada nova situação comunicativa, a escrita se torna um desafio; por isso, é desenvolvida a partir de avanços e retrocessos. No intuito de norteá-lo no processo, o Caderno fornece-lhe algumas sugestões:

- O que eu disse até agora? O que estou tentando dizer?

- Será que eu gosto do que escrevi? O que é tão bom aqui, que eu possa entender? O que não é bom que eu possa arrumar?

- Como meu texto soa? Como parece?

- O que meu leitor ou leitora pensará, quando ler isto? Que indagações poderão fazer? O que observarão? Sentirão? Pensarão?

- E o que farei a seguir?

(CALKINS, 2003 apud BRASIL, 2008a, p. 104-105).

Essas orientações teórico-metodológicas revelam uma preocupação em capacitar o professor, e posteriormente seu aluno, para que produzam textos coesos e coerentes, porque podemos observar aquialgumas "dicas" mais concretas, que contribuem, de fato, para o direcionamento de ambos no processo de planejamento, releitura e reescrita de textos vários. Nessas "dicas", percebe-se um tom voltado para a discursividade. Entretanto, como as condições de produção do discurso não são enfatizadas no material formativo, na prática, isto é, nas propostas, não há suporte necessário para o desenvolvimento/aperfeiçoamento da escrita do professor/cursista. Conhecer e saber aplicar tal conceito, sem dúvida, ajudaria o docente, em grande medida,no seu processo de escritura de um texto e lhe permitiria ensinar seus alunos, podendo tornar-se autores ativos de suas produções escritas.

Em relação às "dicas" oferecidas pelo TP, tais procedimentos e estratégias utilizados pelo produtor de texto de maneira consciente lhe permitem controlar e assumir a sua própria aprendizagem. Mas, ressaltamos que tudo isso só terá significado concreto se acompanhado de um projeto definido de escrita, ou melhor, se o escritor tiver clareza quanto ao seu papel de locutor, do interlocutor, do gênero, do suporte, das intenções de sua escrita, enfim, das condições de produção do texto. Como bem destaca Morles (2003, apud MENEGASSI, 2005, p. 02) [ênfase adicionada],

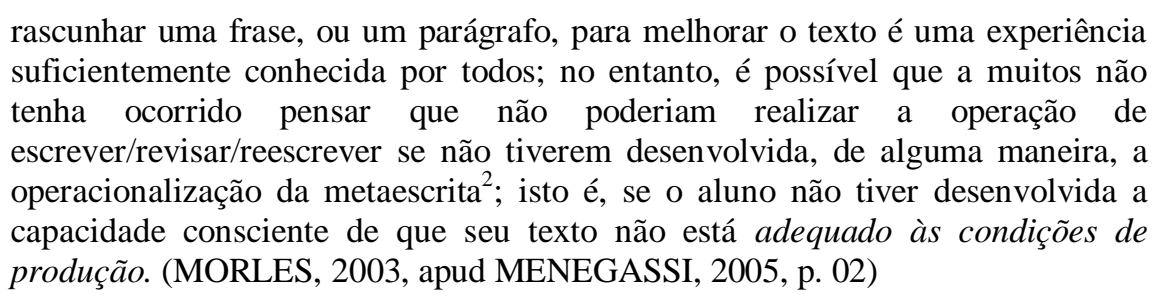

Numa proposta de produção de textos destinada ao aluno, o TP6 apresenta o texto "Dançar para não dançar, a história do Brasil negro" (Anexo 1), retirado de uma revista, e uma foto com objetos de percussão, acompanhados da seguinte questão para o professor:

\footnotetext{
${ }^{2}$ Metaescrita é a utilização consciente de estratégias de produção textual (MENEGASSI, 2005, p. 2).
} 
a) Faça um planejamento para uma seqüência de aulas de produção textual sobre uma tradição cultural de sua região elou cidade. Considere a situação sócio-comunicativa e as atividades que auxiliarão seus alunos na atividade de pré-escrita, no planejamento e escrita de um texto informativo. Se o espaço abaixo for curto, utilize uma folha de seu caderno de apoio.

(BRASIL, 2008, p.106-107)

A respeito desse exercício, podemos inferir que o Caderno TP6 assume a capacitação do professor/cursista, a essa altura do curso, para preparar uma produção de texto significativa para o aluno e que contribua, efetivamente, para desenvolver seu aprendizado e suas capacidades de escrita. Por isso, solicita-lhe o planejamento de uma sequência de aulas de produção textual, destacando a necessidade de considerar as atividades de pré-escrita (leitura de vários textos em gêneros, discussão em grupo etc.), de planejamento (organização das ideias, rascunhos, esboços) e de escrita (revisão, releitura, reescrita). São etapas fundamentais para qualquer processo de produção de textos, pois permitem ao escritor a construção de conhecimentos, bem como a monitoração do processo de produção de texto.

Nesse planejamento, o cursista deve levar em conta a situação sociocomunicativa, isto é, o gênero, o locutor, o interlocutor, o espaço, a intenção etc. Mas é difícil imaginar que o professor irá considerar tais aspectos se, nessa Unidade 22, a maioria das atividades propostas pelo TP6 não os contemplou efetivamente. A nosso ver, o participante não foi (in)formado e nem treinado para desenvolver e aplicar tal conteúdo.

Para a atividade, o TP fornece apenas o assunto a ser abordado (tradição cultural da região) e a característica muito vaga do texto (informativo) - todo texto é, em princípio, informativo - mas não apresenta uma finalidade específica de tal escrita. É necessário considerar, porém, que uma atividade como essa precisa ter, além de um objetivo bem delimitado, um motivo claro que faça algum sentido para o aluno/escritor, que o envolva em um contexto próximo de sua realidade, despertando nele a motivação para escrever.

O TP deixa de indicar também o gênero no qual a escrita se realizará, o que, a nosso ver, é uma falha grave, já que toda escrita se constitui no interior de um gênero do discurso. Diante disso, o materialparece, mais uma vez, ignorar que todo texto se organiza dentro de determinado gênero em função das intenções comunicativas do locutor, como parte das condições de produção dos discursos, assim como propõem as diretrizes oficiais, nas quais o Guia Geral (BRASIL, 2008b) diz se pautar.

No Avançando na prática dessa Seção são apresentados dois textos: um intitulado "Origem do carnaval", de Cláudia M. A. R. Lima (Anexo 2), retirado de um site da internet, e outro sobre o maracatu (Anexo 3), acompanhados de cinco questões:

1. Desenvolva uma pesquisa com seus alunos sobre uma das histórias que são contadas nessas festas: bumba-meu-boi, maracatu, festa de reis, cavalhada, festas indígenas ou mesmo de culturas européias e asiáticas que migraram para o Brasil etc. que sejam conhecidas por seus alunos. Se não tiver uma em especial na região onde você leciona, converse com eles e conte algumas das mencionadas de outras regiões resumidamente e faça uma votação para escolher uma. Se você tiver muito material à disposição para ser lido, pode dividir os grupos de forma que cada um trabalhe uma história diferente.

2. Após a escolha, traga uma dessas narrativas e leia para eles as informações. Você pode mesmo trazer ma pessoa idosa que represente um desses grupos para que conte a história para as suas turmas. 
3. Ofereça materiais variados para eles consultarem ou leve-os à biblioteca ou ao arquivo público para trabalharem com diversos textos verbais e não-verbais sobre a festa.

4. Peça então para que eles narrem a história contada nessas festas para que faça parte de um quadro informativo em um jornal. Além da história, o jornal pode ter uma chamada para a matéria na primeira folha e uma breve reportagem no caderno de cultura do jornal, acompanhada por uma imagem (desenho) e pelo quadro. Você pode planejar para que as atividades sejam desenvolvidas em grupo.

5. Peça que exponham seus jornais no varal de textos da sala, depois de terem lido seus trabalhos para a sala de aula.

(BRASIL, 2008a, p. 109).

Essas questões permitem inferir a tentativa de uma proposta direcionada para o planejamento da escrita, confirmando o objetivo principal da unidade, tendo em vista que enfatiza aqui o procedimento de pré-escrita.

A sugestão para esse trabalho de pré-escrita pode ser vista ao longo da proposta, como, por exemplo, na indicação de que o professor pesquise com seus alunos sobre variadas histórias de carnaval; conte-lhes alguma dessas histórias; converse sobre elas; leiaas para eles; traga uma pessoa idosa para contar histórias para a turma; oportunize a consulta de variados materiais; visite a biblioteca ou o arquivo público com os alunos; trabalhe com vários textos verbais e não verbais. Esses são atributos relevantes, ou melhor, fundamentais para o processo de produção textual, pois se mobilizam aí as capacidades discursivas que ajudam na construçãodo conteúdo do texto.

No ensino-aprendizagem de escrita, concordamos com Schneuwly e Dolz (2004), que advogam em favor da criação de um contexto de produção preciso, com objetivo claro, e da realização de atividades múltiplas e variadas. São essas ações que permitirão ao aluno se apropriar dos instrumentos e das técnicas necessárias ao desenvolvimento de suas capacidades de escrita: a capacidade de ação, que se refere à adaptação das características do contexto de produção de um texto; a capacidade discursiva, que corresponde àmobilização de modelos discursivos, da forma composicional de cada gênero, e a capacidade linguístico-discursiva, que se volta para o domínio das operações psicolinguísticas e das unidades linguísticas que tornam o texto coerente.

A proposta fornecida pelo Caderno apresenta ricas situações de aprendizagem (visitar a biblioteca, ir ao arquivo público), visto que contribuem tanto para despertar a atenção e o interesse do aprendiz como para tornar a aula diferente, menos monótona ou, por vezes, repetitiva e cansativa. Ademais, o contato com a diversidade de textos, acompanhado de uma orientação adequada ao objetivo de ensino, também pode ser uma atividade produtiva, pois o aluno acaba aprendendo a buscar, nos aspectos verbais e não verbais do texto, os índices que lhe possibilitem o uso de seu conhecimento prévio e de seu conhecimento linguístico, indispensáveis para a compreensão textual. Reiteramos, porém, que, para isso, é preciso ter metas bem definidas, que deem condições para o aluno decidir quais os conhecimentos necessários para a construção do significado do texto que lê (KATO, 1985 apud PAES DE BARROS, 2005, p. 22).

As atividades grupais merecem destaque nesse exercício, pois favorecem a interação entre o $e u$ e o outro. É justamente nessa relação que o aluno, um ser social e empírico, torna-se um sujeito responsivo, pois a enunciação possibilita ao aprendiz dialogar com os outros discursos, tomando-os para si, imprimindo sua voz, numa compreensão ativa responsiva, permitindo também um posicionamento, uma apreciação valorativa sobre tal discurso. 
De resto, o trabalho de pré-escrita pode fornecer informações que auxiliem, de fato, na elaboração temática, ajudando o aluno a determinar o tema, o assunto do gênero a ser produzido, conforme Barros-Mendes (2005). Mas deve-se lembrar que, para isso ocorrer de modo efetivo, o aprendiz precisa ter claro o objetivo desse trabalho, o que não parece ocorrer nessa proposta. Como podemos ver na orientação, é somente no quarto momento - em que certamente já tenham se passado algumas aulas - que o TP anuncia a produção: a narração de uma história contada em festas de carnaval.

A partir desses dados, podemos depreender uma tentativa, por parte do Caderno, de propor uma sequência de atividades que culminasse na produção de alguns gêneros jornalísticos (um quadro informativo em um jornal; uma chamada para a matéria na primeira folha, ou uma breve reportagem no caderno de cultura do jornal, acompanhada por uma imagem e pelo quadro). Nota-se que o TP6 se refere a alguns gêneros de modo impreciso.

Como se observa, esses pressupostos do Guia parecem não se materializar na proposta do material. Portanto, falta diálogo entre o TP6 e o Guia Geral. Dizemos isso porque, a nosso ver, não houve aqui uma real preocupação em explorar os elementos constitutivos de cada um dos gêneros do discurso, haja vista que cada um deles possui uma característica específica, que precisa ser ensinada, por meio de um trabalho didático sistematizado.

É pertinente dizer que o TP não demonstra, nessa proposta de ensino-aprendizagem de escrita, a necessidade de se definir o gênero, explorando as estratégias implicadas no seu uso. Parece mesmo apostar na mera visitação do aluno ao gênero.

Agindo de acordo com essa perspectiva, compreendemos que seja muito difícil, para não dizer impossível, desenvolver a autonomia dos alunos, conforme propõe o Guia Geral (BRASIL, 2008b). Afinal, a autonomia - palavra de ordem dos documentos oficiais - é dependente da apropriação consciente e reflexiva não só de informações, como também de estratégias diversas que permitem a construção e o domínio das diferentes formas de dizer, nas mais diversas situações de comunicação humana.

Em relação, às capacidades de linguagem requeridas no processo de escrita, nessa proposta são mobilizados -tangencialmente - alguns elementos da capacidade de ação, a saber, os gêneros (quadro informativo; chamada para a matéria; reportagem), indicados, mas não definidos nem explorados; os interlocutores (alunos da sala); o suporte (jornal); e a finalidade (leitura na sala e exposição no varal de texto da sala).

Fornecem-se também informações que dizem respeito às capacidades discursivas, sobretudo, acerca da construção do conteúdo/assunto a ser tratado. O momento de préescrita constitui-se em um bom exemplo de mobilização desse aspecto, já que possibilita ao aluno não só a leitura de vários gêneros, como também o debate sobre o assunto. Nessa capacidade, contempla-se ainda a dimensão da organização textual, que ocorre quando se informa a sequência (narrativa) na qual se realizará um dos gêneros (quadro informativo).

Para a ativação da capacidade linguístico-discursiva, as dimensões como operação de textualização, tomada de posição enunciativa e seleção lexical não se apresentam, isto é, a proposta não oferece elementos que contribuem para a construção do estilo do gênero ou dos gêneros. Consequentemente, a falta de assimilação dessas capacidades de escrita limita a participação do professor e do aluno não só nas atividades escolares, como também nos variados contextos sociais.

No último momento da atividade, depois da produção textual, é proposta ao aluno a leitura do seu texto para os colegas de classe e, em seguida, a exposição no varal de textos da sala. Notemos que, assim como na última atividade direcionada ao aluno (no Avançando na prática), os leitores dos textos produzidos são exclusivamente o professor e os próprios os alunos. Nesse sentido, acreditamos que, mesmo definindo o público alvo, essa proposta, 
assim como a precedente, poderia ser mais significativa, quando não atrativa, para os alunos, se extrapolasse os "muros da escola", algo que lhes possibilitasse uma experiência real com o uso social da escrita.

Parece que os encaminhamentos de produção feitos pelo TP, na sua maioria, não tiveram um propósito mais concreto, social, pois acabaram encerrados dentro da própria escola; em algum caso, o mural da sala de aula foi o suporte mais lembrado. A ausência de um propósito comunicativo real, sem dúvida, limita o uso da escrita e o aprendizado de sua dimensão pública, interativa e dialogada. Costa Val (2003, p. 36) alerta que, "quando a única possibilidade de socialização da escrito se limita, invariavelmente, à sala de aula, esse procedimento pode perder o caráter de promoção de interlocução para assumir o de ritual obrigatório e sem sentido".

Um trabalho - sistematizado - de revisão e de reescrita, que envolve várias avaliações, correções e versões do texto, constitui-se como etapas inerentes ao processo de escrita. Tendo isso em vista, notamos que nessa proposta elaborada pelo TP6 houve a falta de uma orientação teórica mais focada nesse aspecto. $\mathrm{O}$ papel do professor e do aluno como principais colaboradores da escrita poderia ter sido mais ressaltado, além de parâmetros e critérios reais de correção/revisão.

\section{Conclusão}

A breve análise apresentada permiteafirmar que o material apresenta algumas lacunas quanto à efetivação da proposta de formar/atualizar/aperfeiçoar o professor para o trabalho com o ensino da produção escrita. Podemos dizer que está, como a maioria dos professores, em uma "fase de transição".

Verificamos que houve algum diálogo entre as orientações teóricas do Guia Geral (BRASIL, 2008b) e as do TP6 (BRASIL, 2008a), mas, em alguns momentos, constatamos incoerências entre os dois Cadernos, como, por exemplo, no encaminhamento didático das atividades de produção textual destinadas ao professor e ao aluno. Também notamoscerta distância entre as sugestões de ensino-aprendizagem de escrita, especialmente, do aluno, e alguns dos pressupostos veiculados no PCNLP (BRASIL, 1997, 1998). Esse distanciamento entre as orientações formativas dificultam a análise crítica sobre os processos de ensino e de autoformação profissional, uma vez que alimenta a desarticulação teoria-prática, tão criticada na formação de qualquer docente, mas, especialmente, no de Língua Portuguesa. Essa desarticulação é um dos argumentos que movem a produção de material formativo, bem como a oferta de cursos de atualização docente, em todo o país.

Quanto ao encaminhamento das atividades de escrita para o aluno, comparado aos pressupostos teóricos apresentados ao professor, percebemos que, mesmodestacando os procedimentos de pré-escrita, planejamento, revisão e rescrita, o TP6 deixa a desejar nas propostas de elaboração textual, porqueparece esvaziar a atividade de escrita de sua dimensão dialógica, de seus aspectos discursivos. Por não apresentar explicitamente orientações embasadas nos referenciais nacionais para o ensino, a proposta torna-se limitada, não contemplando a prática efetiva dos conceitos de gêneros do discurso esuas condições de produção escrita.

Consequentemente, o processo de letramento do professor, indispensável à sua formação para o ensino da leitura e da escrita, torna-se igualmente limitado, colidindo com a proposta assumida pelo material de formação continuada, a saber, a capacitação do professor para melhor exercer sua função. Assim, tanto a apreensão dos conceitos assumidos pelo atual paradigma de ensino quanto a possibilidade de reflexão sobre a própria ação, por meio de sua prática pedagógica reflexiva nessa ação e sobre ela, deixam de ser efetivamente propostas e realizadas pelo material analisado. 
Reafirmamos nossa compreensão do espaço de formação continuada como um lugar por excelência para a formação/atualização/aperfeiçoamento dos saberes do professor. Assim, consideramos que o encaminhamento para a produção textual (tanto do professor quanto do aluno) deve inserir-se em um processo de interlocução ativa, a fim de caracterizar a escrita como prática cidadã. Uma alternativa viável é que odocente torne-se um sujeito responsivo, capaz de estabelecer o diálogo com os discursos sociais que produz e em que vive imerso, assumindo uma atitude compreensiva ativa responsiva diante de seu papel de formador e da sua responsabilidade pelo desenvolvimento do domínio da leitura e da escrita, por parte de seus alunos. Para isso, a única solução é formar melhor o professor.

\section{REFERÊNCIAS}

BAKHTIN, M. M. ([1952-1953]). Os gêneros do discurso. In: BAKHTIN, M. M. Estética da Criação Verbal. Traduzido por Paulo Bezerra. 4 ed. São Paulo: Martins Fontes, 2003.

BAKHTIN, M. M.; VOLOSHINOV, V. N. ([1929]). Marxismo e Filosofia da Linguagem. Traduzido por Michel Lahud e Yara Frateschi Vieira. 12 ed. São Paulo: Hucitec, 2004.

BARBOSA, J. P. Trabalhando com os gêneros do discurso: uma perspectiva enunciativa para o ensino de língua portuguesa. Doutorado em Linguística Aplicada ao Estudo de Línguas, do Programa de Pós-Graduação em Linguística Aplicada ao Estudo de Línguas da Pontifícia Universidade Católica de São Paulo, 2001.

BARROS-MENDES, A. N. N. A linguagem oral nos livros didáticos de língua portuguesa do Ensino Fundamental - $3^{o}$ e $4^{a}$ ciclos: algumas reflexões. São Paulo: PUC, 2005. Doutorado em Linguística Aplicada e Estudos da Linguagem, do Programa de PósGraduação em Linguística Aplicada e Estudos da Linguagem da Pontifícia Universidade Católica de São Paulo, 2005.

BRASIL. Introdução aos Parâmetros Curriculares Nacionais. Brasília: Ministério da Educação, Secretaria da Educação Fundamental, 1997.

BRASIL. Parâmetros Curriculares Nacionais $3^{\circ}$ e $4^{o}$ ciclos do Ensino Fundamental: língua portuguesa. Brasília: Ministério da Educação, Secretaria da Educação Fundamental, 1998.

BRASIL. Programa Gestão da Aprendizagem Escolar GESTAR II: Guia Geral. Brasília: $\mathrm{MEC} / \mathrm{SEF}, 2008 \mathrm{~b}$.

BRASIL. Programa Gestão da Aprendizagem Escolar GESTAR II: TP 6. Brasília: MEC/SEF, 2008a.

BRITO, A. E. Formar professores: rediscutindo o trabalho e os saberes docentes. In: MENDES SOBRINHO, J. A. C.; CARVALHO, M. A. (Org.) Formação de professores e práticas docentes: olhares contemporâneos. Belo Horizonte: Autêntica, 2006. p. 41-54.

COSTA VAL, M. G. Atividades de produção de textos escritos em livro didáticos de $5^{\mathrm{a}}$ a $8^{\text {a }}$ séries do Ensino Fundamental. In: ROJO, R.H.R.; BATISTA, A. A. G. (Org.) Livro Didático de Língua Portuguesa: letramento e cultura da escrita. Campinas, SP: Mercado de Letras, 2003. p. 48-74.

DOLZ, J.; SCHNEUWLY, B. Pour un enseignement de l'oral: iniciation aux genres formels à école. Paris: ESF, 1998. 
FREITAS, M. T. A. Vygotsky e Bakhtin. Psicologia e Educação: um intertexto. 4 ed. São Paulo: Ática, 2006.

KLEIMAN, A. B. (org.) A formação do professor: perspectivas da linguística aplicada. Campinas, SP: Mercado de Letras, 2001.

MAGALHÃES, L. M. Modelos de educação continuada: os diferentes sentidos da formação reflexiva do professor. In: KLEIMAN, A. B. (Org.) A formação do professor: perspectivas da linguística aplicada. Campinas: Mercado de Letras, 2001. p. 239-259.

MAGALHÃES, M. C. M. (org.) A formação do professor como um profissional crítico: linguagem e reflexão. Campinas, SP: Mercado de Letras, 2004.

MENEGASSI, R. J. Interação, escrita e metaconsciência na formação de professores. IV Congresso Internacional da Associação Brasileira de Linguística, Brasília. Anais. Universidade de Brasília, 2005. Disponível em:

<http://www.escrita.uem.br/escrita/pdf/rmenegassi2.pdf〉. Acesso em: 10 dez. 2010.

NÓVOA, A. Professores: imagens do futuro presente. Lisboa: Educa, 2009.

OLIVEIRA, M. B. F. de. Revistando a formação de professores de língua materna: teoria, prática e construção de identidades. Revista Linguagem em (Dis)curso, v. 6 . n. 1, jan.-abr. 2006. Disponível em:

<http://www3.unisul.br/paginas/ensino/pos/linguagem/0601/8\%20art\%206.pdf $>$ Acesso em: 01 out. 2011.

PAES DE BARROS, C. G. Compreensão ativa e criadora: uma proposta de ensinoaprendizagem de leitura do jornal impresso. Doutorado em Linguística Aplicada e Estudos da Linguagem, do Programa de Pós-Graduação em Linguística Aplicada e Estudos da Linguagem da Pontifícia Universidade Católica de São Paulo, 2005.

PAES DE BARROS, C. G. Os gêneros discursivos: contribuições teóricas e aplicadas ao ensino de línguas. In: PETRONI, M. R. (Org.) Gêneros do discurso, leitura e escrita: experiências de sala de aula. São Carlos: Pedro \& João Editores/Cuiabá: EdUFMT, 2008.

POMPÍLIO, B. W; MORI-DE-ANGELIS, C. C.; OLIVEIRA, H. A. D.; SILVA, I. D.; BARBOSA, M. S.; NUNES, R. H. Os PCNs: uma experiência de formação de professores do Ensino Fundamental. In: ROJO, R.H.R. (Org.) As práticas de linguagem em sala de aula: praticando os PNCs. Campinas, SP: Mercado de Letras, 2001. p.93-126.

PORTO, Y. S. A Prática de linguagem em sala de aula: praticando os PCNs. São Paulo: EDUC/Campinas, SP: Mercado de Letras, 2001.

PORTO, Y. S. Formação continuada: a prática pedagógica recorrente. In: MARIN, A. J. (Org.). Educação continuada: reflexões, alternativas. Campinas, SP: Papirus, 2000.p. 1138.

PORTO, Y. S. Osgêneros escolares: das práticas de linguagem aos objetos de ensino. Revista Brasileira de Educação. $\mathrm{N}^{\circ}$ 11. Mai/Jun/Jul/Ago1999. Disponível em: http://www.anped.org.br/rbe/rbedigital/RBDE11/RBDE11_03_BERNARD_E_JOAQUIM. pdf. Acesso em: 01 out. 2011.

SCHNEUWLY, B.; DOLZ, J. (Org.) Gêneros orais e escritos na escola. Trad. e org. Roxane Rojo e Glaís Sales Cordeiro. Campinas, SP: Mercado de Letras, 2004.

SCHÖN, D. A. Formar professores como profissionais reflexivos. In: NÓVOA, A. Os professores e sua formação. Lisboa: Dom Quixote, 1992. p. 79-92. 
SILVA, J. Q. G.; ASSIS, J. A.; MATENCIO, M. L. M. Formação inicial e letramento do professor de Português: uma proposta em implantação. In: KLEIMAN, A. B. (Org.) A formação do professor: perspectivas da linguística aplicada. Campinas, SP: Mercado de Letras, 2001. p. 281-309.

SILVA, W. R. Construção de aprendizes de leitura e escrita através de exercícios didáticos: um estudo de caso. Campinas, SP: UNICAMP. Doutorado em Linguística Aplicada no Instituto de Estudos da Linguagem, na Universidade Estadual de Campinas, 2006.

SOCORRO, A. Os gêneros do discurso e a formação docente Gestar II: um olhar enunciativo-discursivo (im)possível. Cuiabá: UFMT, 2009. (Mestrado em Estudos de Linguagem) do Programa de Pós-Graduação em Estudos de Linguagem da Universidade Federal de Mato Grosso, 2009.

STRIQUER, M. S. D. O livro didático na formação do professor de língua portuguesa. $17^{\circ}$ COLE, 2009. Disponível em:

<http://www.alb.com.br/anais17/txtcompletos/sem20/COLE_887.pdf>. Acesso em: 01 out. 2011.

VÓVIO, C. L; SOUZA, A. L. S. Desafios metodológicos em pesquisas sobre letramento. In: KLEIMAN, A. B.; MATENCIO, M. L. M. (org.). Letramento e formação do professor: representações e construção do saber. Campinas, SP: Mercado de Letras, 2005. p. 41-64.

VYGOTSKI, L. S. ([1984]). A formação social da mente. 7 ed. São Paulo: Martins Fontes, 2007.

VYGOTSKI, L. S. ([1987]) Pensamento e Linguagem. São Paulo: Martins Fontes, 1996.

Recebido em outubro de 2011.

Aprovado em novembro de 2012. 
ANEXO 1

Atividade 8

Leia o texto abaixo.

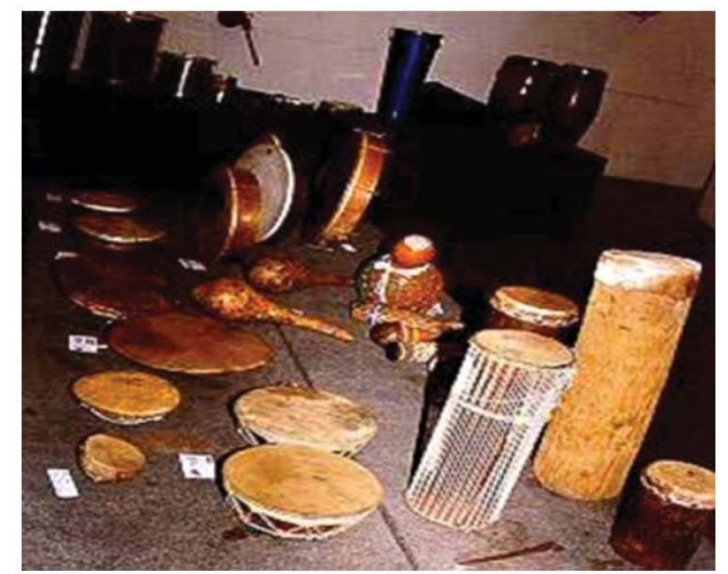

http://www.nics.unicamp.br/nicsnews/001/img/atual/noticia_percussao.jpg

\section{Dançar para não dançar, a história do Brasil negro}

Tambores bicentenários esquentam um arraial em Minas Gerais. Numa comunidade pobre do Rio, meninos tocam a grave angoma puíta - que originou a cuíca - e louvam a tradição banto. Baianos, de quatro a 80 anos, batem paus e panelas e dão nova vida ao maculelê e ao samba-de-roda nas ladeiras do Pelourinho. Ao Norte, no Recife, um grupo de maracatu de 140 anos faz tremer os paralelepípedos e tira a respiração dos jovens. Dançar, batucar e cantar sempre foram as mais usuais - por menos reprimidas ou mais abstratas - formas de resistência dos negros brasileiros.

É assim quando três tambores trazidos da África há cerca de 230 anos ecoam na propriedade de $122 \mathrm{mil}$ metros quadrados que Artur Camilo Silvério deixou para os herdeiros, hoje na sexta geração, em Contagem (MG). A Comunidade Arturos, batizada com o nome do fundador, tem um extenso calendário de celebrações: em maio, a Festa da Libertação da Escravidão leva às ruas o cortejo de "escravos" acorrentados; em outubro, é a vez da Festa de Nossa Senhora do Rosário, "a santa protetora dos homens de cor" e padroeira do "Congado"; e, dezembro, os maus espíritos são expulsos da lavoura na Festa de João do Mato.

(...) "O objetivo é preservar a tradição, mas não temos escola ou oficina, apenas a convivência", concorda João Batista da Cruz, presidente de honra da Irmandade de Nossa Senhora do Rosário de Contagem. Ele é um dos líderes da comunidade patriarcal, que atualmente se remete ao neto mais velho de Artur Camilo, Geraldo Artur Camilo, de 90 anos, o rei do Congo em Minas Gerais. João afirma que os Arturos "dançam desde a

barriga da mãe" moçambique, congo, afoxé e o candomblé, que ele diz ser o pai do jongo carioca. Parentes com certeza são.

Na Serrinha, comunidade do Rio que abriga uma das mais importantes escolas de samba do país, o Império Serrano, a tradição se renova na ONG e Centro Cultural Jongo da Serrinha. "Aqui os mais jovens aprendem a história dos antepassados que chegaram a Serrinha e o que eles deixaram. A dança do jongo veio de Angola por volta de 1600 . Com a abolição da escravatura, os jongueiros vieram para cá, onde fundariam o Império Serrano", resume Rodrigo Nunes, coordenador do Centro, que este mês abrirá uma filial na favela do Acari para levar o ensinamento do jongo, segundo ele, o pai do samba".

(...)

Revista Nossa História, fevereiro, 2004: 08 
ANEXOS 2 E 3

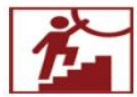

Avançando na prática

Nas diferentes tradições de carnavais, sabemos que o uso de máscaras e fantasias tem significados diferentes. Também na festa de Carnaval de Veneza, na Itália, o uso de máscaras e fantasias são quesitos indispensáveis e foi lá que as fantasias de Arlequim, Pierrô e Colombina começaram a ser imortalizadas. Leia o trecho abaixo sobre as origens do Carnaval.

\section{Origem do Carnaval}

Dez mil anos antes de Cristo, homens, mulheres e crianças se reuniam no verão com os rostos mascarados e os corpos pintados para espantar os demônios da má colheita. As origens do carnaval têm sido buscadas nas mais antigas celebrações da humanidade, tais como as Festas Egípcias que homenageavam a deusa ísis e o Touro Apis. Os gregos festejavam com grandiosidade, nas Festas Lupercais e Saturnais, a celebração da volta da primavera, que simbolizava o Renascer da Natureza. Mas num ponto todos concordavam, as grandes festas, como o carnaval, estão associadas a fenômenos astronômicos e a ciclos naturais. O carnaval se caracteriza por festas, divertimentos públicos, bailes de máscaras e manifestações folclóricas. Na Europa, os mais famosos carnavais foram ou são: os de Paris, Veneza, Munique e Roma, seguidos de Nápoles, Florença e Nice.

Lima, Cláudia M. de Assis Rocha. Em História do Carnaval. Site da Fundação Joaquim Nabuco, www. fundaj.gov.br, consultado em 23 de fevereiro de 2006

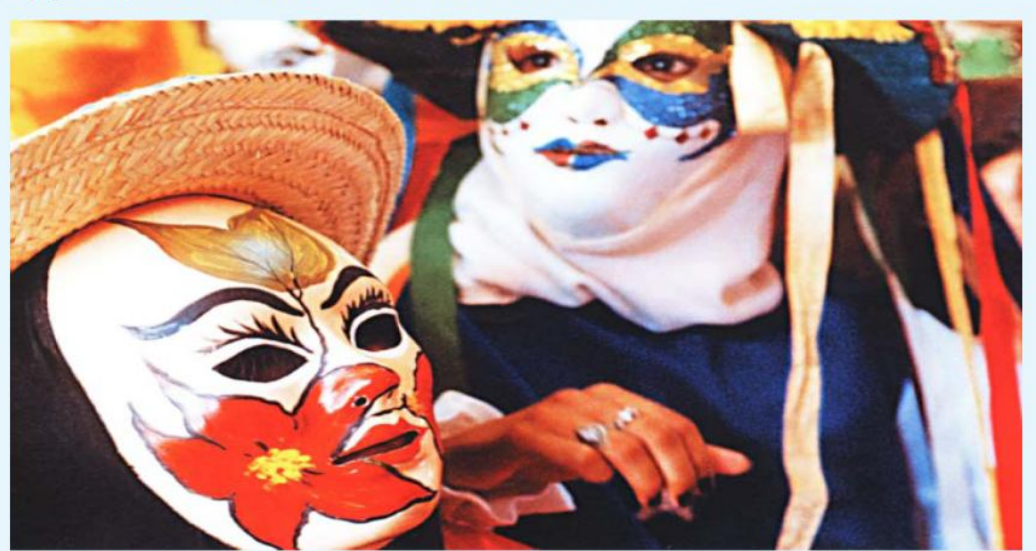

Em Bezerros, a $100 \mathrm{~km}$ do Recife, três mil papangus vão às ruas no domingo de Carnaval. Continente 1 (7), 2003 p. 31.

Também no Brasil temos diferentes tradições, no Norte e Nordeste, as festas muitas vezes contam histórias e as fantasias e máscaras representam personagens, como é o caso do Maracatu Rural de Pernambuco.

Leia o trecho seguinte. 


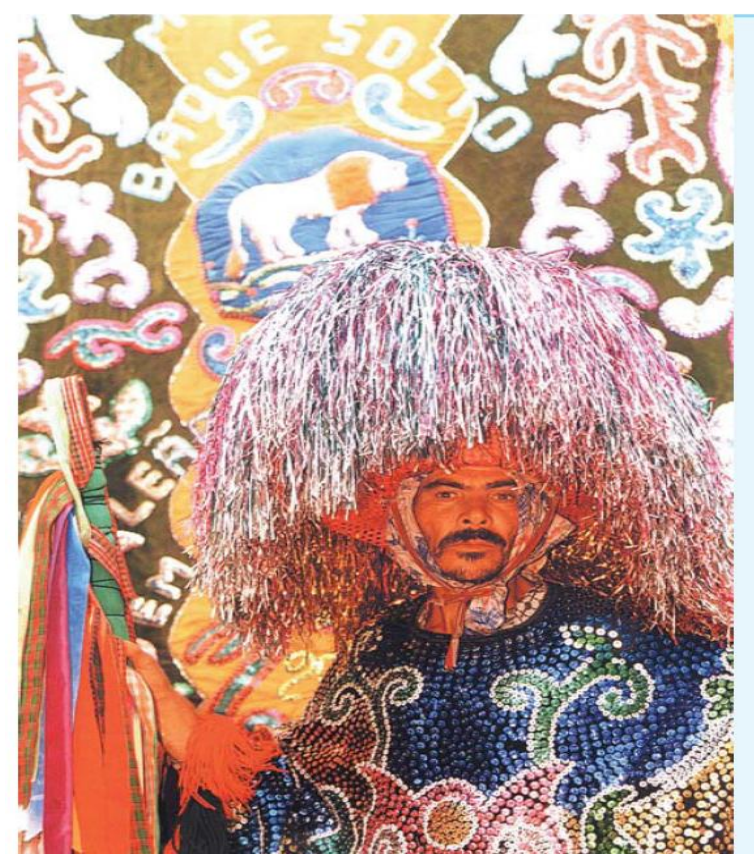

"(...)

A imagem mais marcante do maracatu rural é a do caboclo de lança [...] - figura estranhíssima que avança pelas ruas como guerreiro de um reino alegórico, com sua cabeleira colorida, feita de tiras de papel celofane ou crepom, sua lança emplumada de fitas, seu manto de veludo negro maravilhosamente bordado de miçangas e lantejoulas, seu rosto pintado de vermelho, óculos escuros, uma rosa preta entre os dentes e ao som de chocalhos que ribombam com seu caminhar.

$$
(\ldots)^{\prime \prime}
$$

Continente 1 (7), 2003 p. 10

Caboclo de lança, um dos ícones do Carnaval pernambucano

Continente 1 (7), 2003 p.11.

1 - Desenvolva uma pesquisa com seus alunos sobre uma das histórias que são contadas nessas festas: bumba-meu-boi, maracatu, festa de reis, cavalhada, festas indígenas ou mesmo de culturas européias e asiáticas que migraram para o Brasil etc. que sejam conhecidas por seus alunos. Se não tiver uma em especial na região onde você leciona, converse com eles e conte algumas das mencionadas de outras regiões resumidamente e faça uma votação para escolher uma. Se você tiver muito material à disposição para ser lido, pode dividir os grupos de forma que cada um trabalhe uma história diferente.

2- Após a escolha, traga uma dessas narrativas e leia para eles as informações. Você pode mesmo trazer uma pessoa idosa que represente um desses grupos para que conte a história para as suas turmas.

3- Ofereça materiais variados para eles consultarem ou leve-os à biblioteca ou ao arquivo público para trabalharem com diversos textos verbais e não-verbais sobre a festa.

4- Peça então para que eles narrem a história contada nessas festas para que faça parte de um quadro informativo em um jornal. Além da história, o jornal pode ter uma chamada para a matéria na primeira folha e uma breve reportagem no caderno de cultura do jornal, acompanhada por uma imagem (desenho) e pelo quadro. Você pode planejar para que as atividades sejam desenvolvidas em grupo.

5- Peça que exponham seus jornais no varal de textos da sala, depois de terem lido seus trabalhos para a sala de aula. 